\title{
Geomorfologi Perairan Muara Sungai Kaliboyo Batang Jawa Tengah
}

\author{
Tyandi Shofian, Warsito Atmodjo, Jarot Marwoto \\ Departemen Oseanografi, Fakultas Perikanan dan Ilmu Kelautan, Universitas Diponegoro \\ Jl. Prof.H.Soedarto S.H, Tembalang,Semarang, Jawa Tengah 50275 Indonesia \\ ${ }^{*}$ Corresponding author, e-mail : shofiantyandi@gmail.com
}

\begin{abstract}
ABSTRAK : Sungai Kaliboyo merupakan salah satu daerah aliran sungai (DAS) yang ada di Kabupaten Batang. Muara Sungai Kaliboyo terletak di Desa Roban, dimana mayoritas masyarakat memanfaatkan sebagai sarana transportasi dan sumber mata pencaharian. Perairan yang dulu digunakan sebagai jalur transportasi kini mengalami perubahan berupa pendangkalan pada aliran muara, sehingga berdampak pada terhambatnya aktivitas nelayan khususnya alur keluar masuk kapal. Informasi geomorfologi ialah hal vital untuk perencanaan dan pemanfaatan perairan di masa mendatang salah satunya pengerukan. Tujuan dari penelitian ini untuk mengetahui kondisi geomorfologi perairan Muara Sungai Kaliboyo, Kabupaten Batang. Penelitian ini dilakukan dengan pemeruman kedalaman menggunakan instrumen singlebeam echosounder tipe Garmin GPSMap 585 untuk mengetahui kedalaman perairan, serta grab sampler untuk mengambil sampel sedimen dasar. Pengolahan data diproses dengan menggunakan software ArcGIS 10.4 dan Surfer 11 untuk mendapatkan hasil kontur batimetri dan persebaran sedimen guna mengetahui kondisi geomorfologi. Berdasarkan hasil penelitian, menunjukkan bahwa muara sungai terjadi pendangkalan hingga kedalaman $0,5 \mathrm{~m}$. Kemiringan perairan berkisar $0,47 \%$ hingga 1,95\% yang dikategorikan datar. Kondisi geomorfologi berupa pantai berpasir dengan didominasi gelombang dan debit sungai.
\end{abstract}

Kata Kunci: Sungai Kaliboyo, Geomorfologi, Batimetri, Singlebeam Echosounder

\section{Geomorfologi Of Kaliboyo Estuary Waters Batang Central Java}

ABSTRACT : Kaliboyo River is one of the river basins (DAS) in Batang Regency. The Kaliboyo River Estuary is located in Roban Village, where the majority of the civilization uses it as transportation route and a source of livelihood. The waters that used to be used as a transportation route are now undergoing changes in the form of siltation in the estuary flow, so that it has an impact on the inhibition of fishing activities, especially the shipping channel, in and out of ships. Geomorphological information is important for the planning and utilization of water in the future, one of which is dredging. The purpose of this study was to determine the geomorphological conditions of the Kaliboyo Estuary waters, Batang Regency. This research was conducted by depth analysis using a Garmin GPSMap 585 singlebeam echosounder instrument to determine the depth of the waters, as well as a grab sampler to take basic sediment samples. Data processing was processed using ArcGIS 10.4 and Surfer 11 software to obtain the results of bathymetry contours and sediment distribution to determine geomorphological conditions. Based on the results of the study, it shows that river mouths shallow to a depth of $0.5 \mathrm{~m}$. The water slope ranges from $0.47 \%$ to $1.95 \%$ which is categorized flat. Geomorphological conditions is sandy beaches dominated by waves and river discharge.

Keywords: Kaliboyo River, Morphology, Bathymetry, Singlebeam Echosounder

\section{PENDAHULUAN}

Sungai Kaliboyo bermuara menuju Laut Jawa, dengan panjang sungai sekitar $40 \mathrm{~km}$ dan luas sekitar 139,3 km2. Sungai ini memiliki debit hilir hingga 443 m3/detik (Dinas Pustadaru, 2012). Muara Sungai Kaliboyo terletak di Desa Roban. Secara administratif Desa Roban terbagi atas Desa Roban Barat yang terletak di Kecamatan Tulis, Kabupaten Batang dan Desa Roban Timur yang terletak di Kecamatan Subah, Kabupaten Batang (BPS Kabupaten Batang, 2018). 
Desa Roban sebagai desa di kawasan pesisir tentunya mayoritas masyarakat menggantungkan kehidupan melalui komoditas bahari. Desa Roban dijadikan pusat aktivitas nelayan, dengan terdapat 2 tempat pelelangan ikan (TPI) pada Dukuh Roban Barat. Sungai Kaliboyo merupakan satu-satunya perairan yang dimanfaatkan sebagai sarana transportasi dan sumber mata pencaharian masyarakat Desa Roban. Perairan Kaliboyo yang terletak di Desa Roban yang dulu digunakan sebagai jalur transportasi kini mengalami perubahan berupa pendangkalan pada aliran muara. Hal ini terjadi karena tingginya material sedimen dasar yang berasal dari debit sungai, erosi serta didukung tingginya aktivitas masyarakat setempat. Hal ini berdampak pada terhambatnya aktivitas nelayan khususnya alur keluar masuk kapal. Geomorfologi memiliki pengaruh untuk mengetahui sedimen yang harus dikeruk. Informasi geomorfologi pada perairan ialah hal yang vital dalam kegiatan pengerukan.

Penelitian ini dilakukan untuk mengetahui kondisi geomorfologi perairan Muara Sungai Kaliboyo. Minimnya informasi mengenal geomorfologi perairan maka diperlukan survei pendugaan dasar laut dengan pengukuran yang aktual sebagai data penunjang dalam pengerukan alur perairan. Survei batimetri menggunakan singlebeam echosounder yang berguna untuk mengukur kedalaman perairan berbasis gelombang suara serta tongkat skala untuk perairan dangkal. Data batimetri diekstraksi menggunakan software MapSource 6.16 serta dikoreksi menggunakan data pasang surut daerah setempat yang telah terverifikasi dengan pasang surut BMKG. Data sedimen dasar laut diambil menggunakan grab sampler. Data sedimen dan batimetri diolah menggunakan software ArcGIS 10.4 dan Surfer 11 menghasilkan peta kedalaman dua dimensi dan tiga dimensi beserta persebaran sedimen dan geomorfologi dasar perairan. Penelitian ini dilakukan di Perairan Kaliboyo, Desa Roban, Kecamatan Subah dan Kecamatan Tulis, Kabupaten Batang, Provinsi Jawa Tengah pada koordinat wilayah $\left(06^{\circ} 53^{\prime} 41,74^{\prime \prime}-06^{\circ} 54^{\prime} 35,15^{\prime \prime}\right)$ Lintang Selatan dan (10950’07,96"- 10950’55,78") BT yang disajikan pada Gambar 1.

\section{MATERI DAN METODE}

Materi yang digunakan pada penelitian ini terdiri dari data batimetri melalui instrumen singlebeam echosounder dan tongkat skala, data pasang surut menggunakan palem pasut pada tanggal 13 15 September 2018 dan data sedimen dasar menggunakan sedimen grab. Data penunjang berupa Peta Rupa Bumi Digital Indonesia skala 1:25.000 lembar 1409-121 terbitan Badan Informasi Geospasial tahun 2000, Peta Lingkungan Pantai Indonesia skala 1:50.000 lembar 1409-02 terbitan Badan Informasi Geospasial (BIG) tahun 2000, data pasang surut September 2018 terbitan Badan Meteorologi, Klimatologi dan Geofisika Maritim Indonesia, dan data gelombang lapangan September 2018 perairan Muara Sungai Kaliboyo.
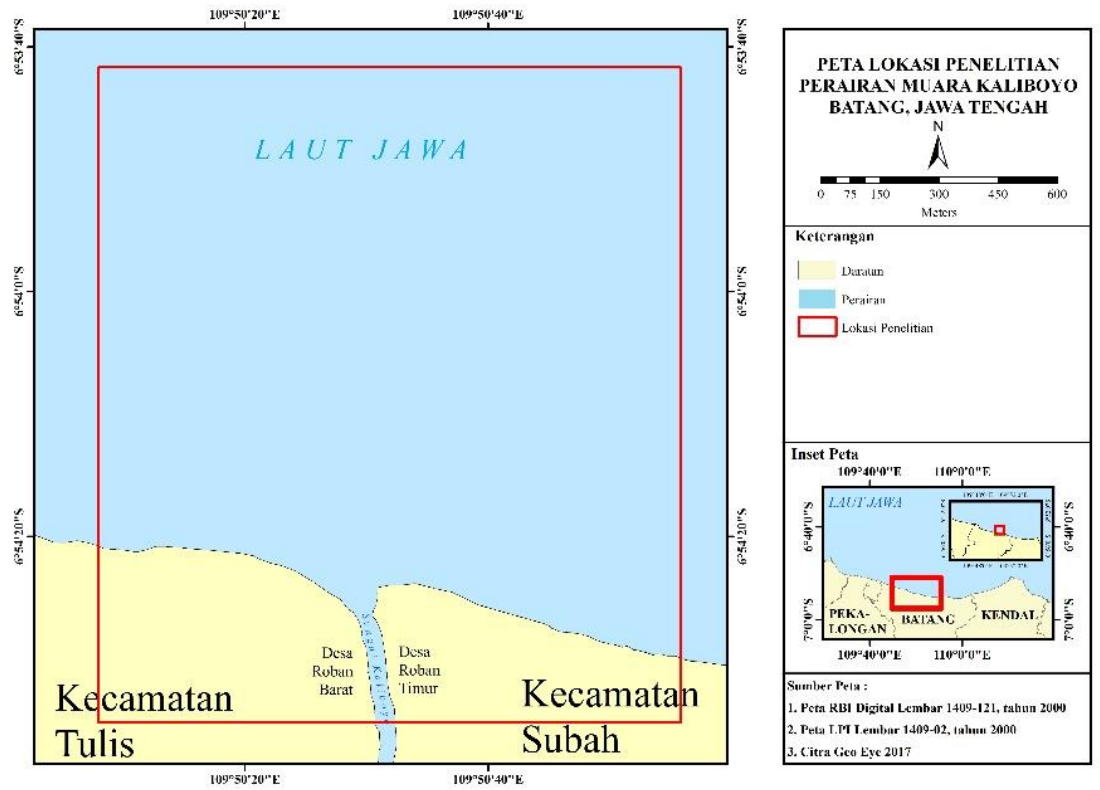

Gambar 1. Peta Lokasi Penelitian Muara Sungai Kaliboyo 
Metode yang dapat digunakan dala penelitian yaitu metode kuantitatif, disebabkan data yang dianalisis berupa angka seperti kedalaman perairan, konstanta pasang surut serta ukuran butir sedimen $\left(D_{50}\right)$. Metode kuantitatif ialah metode dengan data penelitian yang diperoleh dan digunakan, berupa angka dan analisis data. Pendekatan ilmiah dilakukan, dengan langkah dan tata urutan tertentu, sehingga mendapatkan hasil yang benar dan logis.(Priyono, 2016).

Pengambilan data batimetri meliputi metode akustik dan metode mekanik. Pada metode mekanik menggunakan tongkat skala diambil sebanyak 12 titik kedalaman menggunakan metode purposive sampling yang mewakili daerah sungai, muara dan perairan dangakal. Pada metode akustik menggunakan singlebeam echosounder dengan wilayah pemeruman $1,2 \mathrm{~km}^{2}$ yang terdiri dari 16 lajur utama dan 2 lajur silang.

Pengamatan pasang surut dilakukan untuk memperoleh data tinggi muka air laut pada lokasi penelitian yang dapat berguna untuk menetapkan datum vertikal penelitian. Pasang surut dilakukan selama 3 hari dengan interval 1 jam. Menurut Standar Nasional Indonesia (SNI) 7646:2010, perekaman data pasang surut dilakukan saat kegiatan pemeruman, sehingga berfungsi untuk keperluan koreksi reduksi data pemeruman. Nilai pasang surut pada saat pemeruman digunakan untuk mendapatkan nilai kedalaman yang sesungguhnya.

Pengambilan sampel sedimen menggunakan sedimen grab dilakukan sebanyak 48 stasiun menggunakan metode purposive sampling dengan mewakili sungai, muara, hingga perairan pantai.

Data pasang surut dari Badan Meteorologi, Klimatologi dan Geofisika diolah menggunakan metode Admiralty untuk memperoleh konstanta pasang surut, seperti $\mathrm{M}_{2}, \mathrm{~S}_{2}, \mathrm{~K}_{1}, \mathrm{O}_{1}, \mathrm{~N}_{2}, \mathrm{~K}_{2}, \mathrm{P}_{1}, \mathrm{M}_{4}$ dan $\mathrm{MS}_{4}$ (Ongkosongo, 1989). Selanjutnya konstanta pasang surut dapat digunakan untuk mendapatkan nilai Mean Sea Level (MSL), Lowest Low Water Level (LLWL), dan Highest High Water Level (HHWL). Kemudian dapat diklasifikasikan tipe pasang surut pada lokasi penelitian melalui bilangan Formzahl.

\section{Pangolahan Batimetri}

Menurut Soeprapto (2001), data hasil pengukuran batimetri harus dikoreksi terhadap kedudukan permukaan air laut (MSL, $Z_{0}$ dan TWLt) pada waktu pengukuran dan dilakukan koreksi termasuk jarak tenggelamnya transduser (koreksi transduser) yaitu $0,5 \mathrm{~m}$ agar diperoleh kedalaman sebenarnya. Reduksi (koreksi) terhadap pasang surut air laut dirumuskan sebagai berikut :

$$
r t=T W L t-\left(M S L+Z_{0}\right)
$$

Keterangan : rt = besarnya reduksi (koreksi yang diberikan kepada hasil pengukuran kedalaman pada waktu $\mathrm{t}$; TWLt = kedudukan permukaan laut sebenarnya (true water level) pada waktu t; MSL : muka air laut rata - rata (Mean Sea Level); Zo : kedalaman muka surutan dibawah MSL.

Persamaan diatas menghasilkan besarnya koreksi terhadap pasang surut air laut dan selanjutnya menghitung kedalaman sebenarnya dengan rumus sebagai berikut:

$$
D=d T-r t
$$

Keterangan $: D=$ kedalaman sebenarnya; $d T=$ kedalaman terkoreksi transduser; $r t$ : keduksi (koreksi) pasang surut laut.

Data kemudian diolah menjadi peta kedalaman dua dimensi dan tiga dimensi menggunakan software Surfer 11 dengan metode interpolasi Kriging dan disusun menggunakan software ArcGIS 10.4 .

\section{Pengolahan Sampel Sedimen Dasar}

Pengolahan sampel sedimen dasar menggunakan analisa granulometri untuk menentukan ukuran butir sedimen. Proses penentuan menggunakan metode sieving atau pengayakan menurut Poerbandono dan Djunarsjah (2005), ukuran butir akan dimasukkan berdasarkan skala Wenthworth dan disusun dalam sieve graph. Kemudian menggunakan ketentuan $D_{50}$ untuk mendapatkan klasifikasi sedimen. Hasil akan berupa peta geomorfologi yang diolah menggunakan software ArcGIS 10.4 untuk mengetahui persebaran sedimen. 


\section{Pengolahan Data Kemiringan}

Kemiringan dasar laut diperoleh dengan menghitung slope (kemiringan) menggunakan peta morfologi dan geomorfologi dari hasil pengolahan data batimetri dan sedimen. Perhitungan kemiringan dasar laut menggunakan persamaan sebagai berikut :

$$
S=\frac{(n-1) \times I c}{\Delta h} \times 100 \%
$$

Keterangan : $\mathrm{S}=$ nilai kemiringan lereng $(\%) ; \Delta \mathrm{h}=$ jarak horizontal $(\mathrm{m})$; $\mathrm{lc}=$ interval kontur; $\mathrm{n}=$ jumlah kontur

Pengklasifikasian nilai kemiringan lereng didasarkan pada klasifikasi Van Zuidam (1982). Klasifikasi kemiringan lereng (slope). Data yang didapatkan juga akan dibuatkan visualisasi penampang melintang morfologi dasar perairan menggunakan bantuan software Surfer 11 .

\section{HASIL DAN PEMBAHASAN}

Hasil analisa pasang surut, nilai tinggi muka air rata-rata $(\mathrm{MSL})$ adalah $62,07 \mathrm{~cm}$, tinggi muka air tinggi (HHWL) adalah 125,94 cm, tinggi muka air rendah (LLWL) adalah 12,91 cm dan muka surutan $\left(Z_{0}\right)$ adalah $63,87 \mathrm{~cm}$. Tipe pasang surut perairan muara Kaliboyo adalah tipe pasang surut campuran harian ganda dengan nilai Formzahl sebesar 0,91.Pada Sungai Kaliboyo, kedalaman berkisar 0,5 hingga $1 \mathrm{~m}$ sebelum mencapai muara. Terlihat adanya cekungan sedalam $2 \mathrm{~m}$ persis sebelum muara sungai. Muara sungai memiliki kedalaman $0,5 \mathrm{~m}$ dan terlihat mengalami penyempitan muara sungai. Kedalaman perairan berkisar 1 hingga $6 \mathrm{~m}$ dan terlihat adanya pola bergelombang menjorok ke muara yang mengikuti garis pantai dan muara sungai (Gambar 2). Kedalaman perairan berjarak $400 \mathrm{~m}$ dari garis pantai dengan kedalaman 1 hingga 3 $\mathrm{m}$ dinilai rapat pada bagian kiri perairan. Kedalaman perairan berjarak $300 \mathrm{~m}$ dari garis pantai dengan kedalaman 1 hingga 3 m dinilai rapat pada bagian kanan perairan. Hal ini diduga adanya pengaruh abrasi dan akresi yang disebabkan oleh gelombang. Hasil model morfologi dasar laut 3 dimensi ini telah di overlay dengan garis kontur dan peta dasar Perairan Muara Sungai Kaliboyo (Gambar 3).

Dengan menggunakan ukuran butir rata-rata (D50), sedimen terbagi menjadi pasir sedang $(0,5-0,25 \mathrm{~mm})$, pasir halus $(0,25-0,125 \mathrm{~mm})$ dan pasir sangat halus $(0,125 \mathrm{~mm}-0,0625 \mathrm{~mm})$. Ukuran butir median D50 adalah diameter sedimen 50\% dari material dasar $(\mathrm{mm})$ dan yang paling banyak digunakan untuk ukuran butir pasir (Triatmodjo, 1999). Nilai ini digunakan untuk mengetahui persebaran sedimen. Pada sungai ditemukan berupa pasir sangat halus. Pada muara hingga perairan pantai ditemukan berupa pasir halus. Pasir sangat halus berasal dari hulu muara
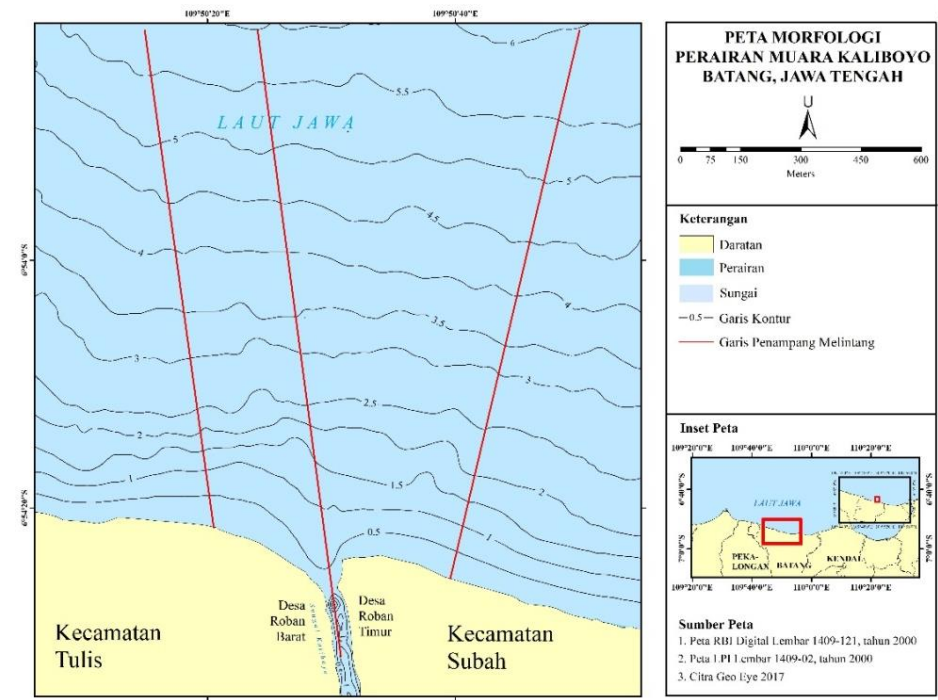

Gambar 2. Peta Morfologi Perairan Muara Sungai Kaliboyo 

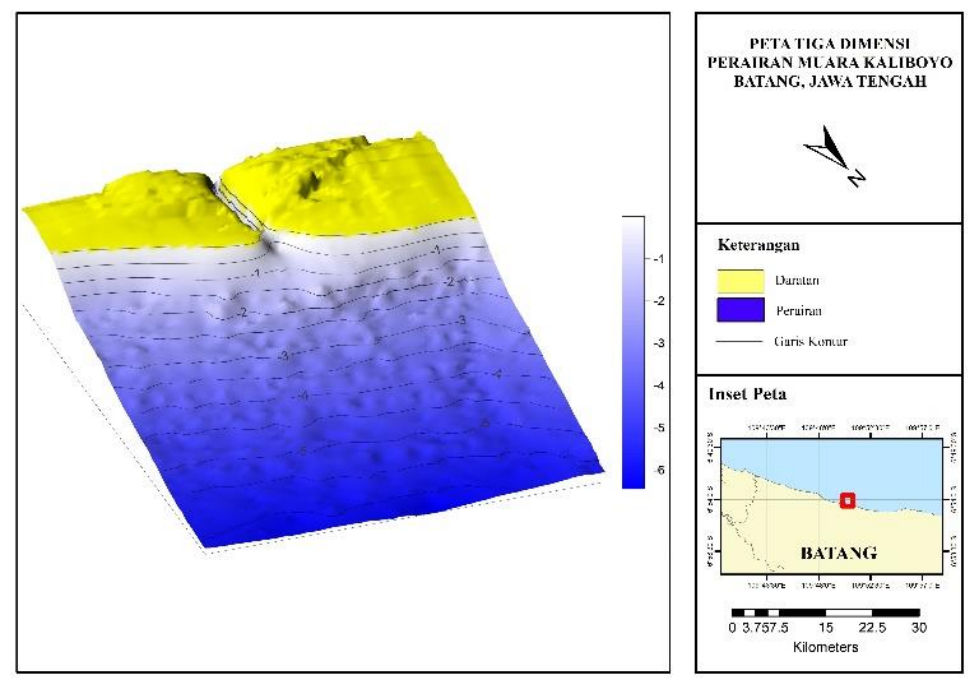

Gambar 3. Model Morfologi Dasar Laut 3 Dimensi Perairan Muara Sungai Kaliboyo

yang kemudian terbawa menuju laut dan berakhir mengendap pada mulut muara. Hal ini disebabkan karena ukuran butir sedimen yang kecil, sehingga sedimen akan tersuspensi. Gelombang laut yang lebih dominan akan bertemu dengan arus sungai yang mengakibatkan kecepatan aliran mendekati nol, mempengaruhi sedimen yang terbawa dari sungai akan mengendap menjadi sedimen dasar dan sebagian akan terbawa ke laut dan pantai di sekitar muara. Sedimen pinggir pantai ditemukan secara keseluruhan berupa pasir sedang. Pada sungai hingga muara, nilai ukuran butir rata-rata pada sedimen yang diambil sebesar $0,10 \mathrm{~mm}$. Terlihat bahwa ukuran butir terkecil berada di sungai hingga muara. Menurut Triatmodjo (1999), semakin menuju kedalaman perairan, maka sedimen yang tersebar akan semakin halus, dan apabila arusnya berkurang maka tidak mampu lagi mengangkut sedimen sehingga akan terjadi sedimentasi di daerah tersebut.

\section{Geomorfologi}

Gelombang memberikan pengaruh paling dominan pada sungai yang bermuara di laut terbuka (luas). Pada suatu muara, ketiga faktor (gelombang, debit sungai dan pasang surut) bekerja secara stimultan, tetapi ada pengaruh yang lebih dominan dari yang lainnya (Triatmodjo, 1999). Muara sungai dan bentuk kontur kedalaman pada Gambar 4 menyerupai perairan yang dipengaruhi oleh gelombang. Hal ini didukung dengan ukuran sedimen di muara tergolong halus. Muara sungai didominasi oleh gelombang, memiliki gosong pasir yang berada di depan mulut sungai yang membuat adanya daratan ketika surut (Colin, 2002). Kemudian apabila data gelombang lapangan ditambahkan untuk mengetahui arah datang, terlihat gelombang sebesar $35^{\circ}$ dari timur laut menuju perairan menyebabkan adanya akresi dan abrasi pada perairan. Akresi merupakan adanya penambahan pantai, terjadi pada sisi kanan perairan terletak pada Kecamatan Subah. Abrasi merupakan adanya pengurangan pantai akibat erosi, terjadi pada sisi kanan perairan terletak pada Kecamatan Tulis. Hal ini dibuktikan pada penampang melintang bahwa sayatan E-F $(0,47 \%)$ relatif memiliki kemiringan lebih kecil daripada sayatan $C-D(0,5 \%)$, sehingga menunjukkan lebih landai. Dasar laut perairan Muara Sungai Kaliboyo memiliki slope yang rendah, slope merupakan ukuran kemiringan dasar laut setiap terjadinya perubahan atau ukuran kemiringan dasar laut yang ditandai dengan satuan persen (\%) (Febrianto et al., 2015). Nilai slope yang diperoleh berkisar $0.47 \%$ hingga $1.95 \%$, sehingga tergolong datar.

Muara ini juga dipengaruhi oleh debit sungai, dengan didukung melalui sayatan pada Gambar 6. Hal ini dikarenakan debit sungai bertemu dengan gelombang. Saat air pasang, kecepatan aliran bertambah besar dan sebagian sedimen dari laut masuk kembali ke sungai, menyebabkan bertemunya sedimen dari hulu. Pada depan muara, penampang melintangnya termasuk kedalam klasifikasi curam seperti pada segmen $\alpha_{3}(5,23 \%)$. Muara ini memiliki gosong pasir pada tepi yang mengakibatkan shelf (paparan) menjadi curam (Triatmodjo, 1999) 


\section{Kelerengan (Slope) Dasar Laut}

Hasil kelerengan dasar laut dapat dikenali berdasarkan bentuk kerapatan pola kontur, lalu diperhitungkan kelerengan (slope) dasar lautnya yang ditentukan menggunakan 3 sayatan (Gambar 5 dan Gambar 6). Hasil perhitungan tersebut dapat diketahui klasifikasi kelerengannya berdasarkan klasifikasi Van Zuidam (Tabel 1).

Penampang melintang digunakan untuk mengetahui bentuk, profil dan ketinggian kontur perairan, dengan cara ditarik garis lurus dari satu titik menuju titik lain. Sayatan A-B mewakili kondisi perairan bagian tengah dengan panjang 1428,78 m. Sayatan C-D ditarik dari pinggir pantai hingga perairan pantai dan mewakili kondisi perairan bagian kiri atau barat dengan panjang $1146,57 \mathrm{~m}$. Sayatan E-F ditarik dari pinggir pantai hingga perairan pantai dan mewakili kondisi perairan bagian kanan atau timur dengan panjang 1283,73 $\mathrm{m}$.
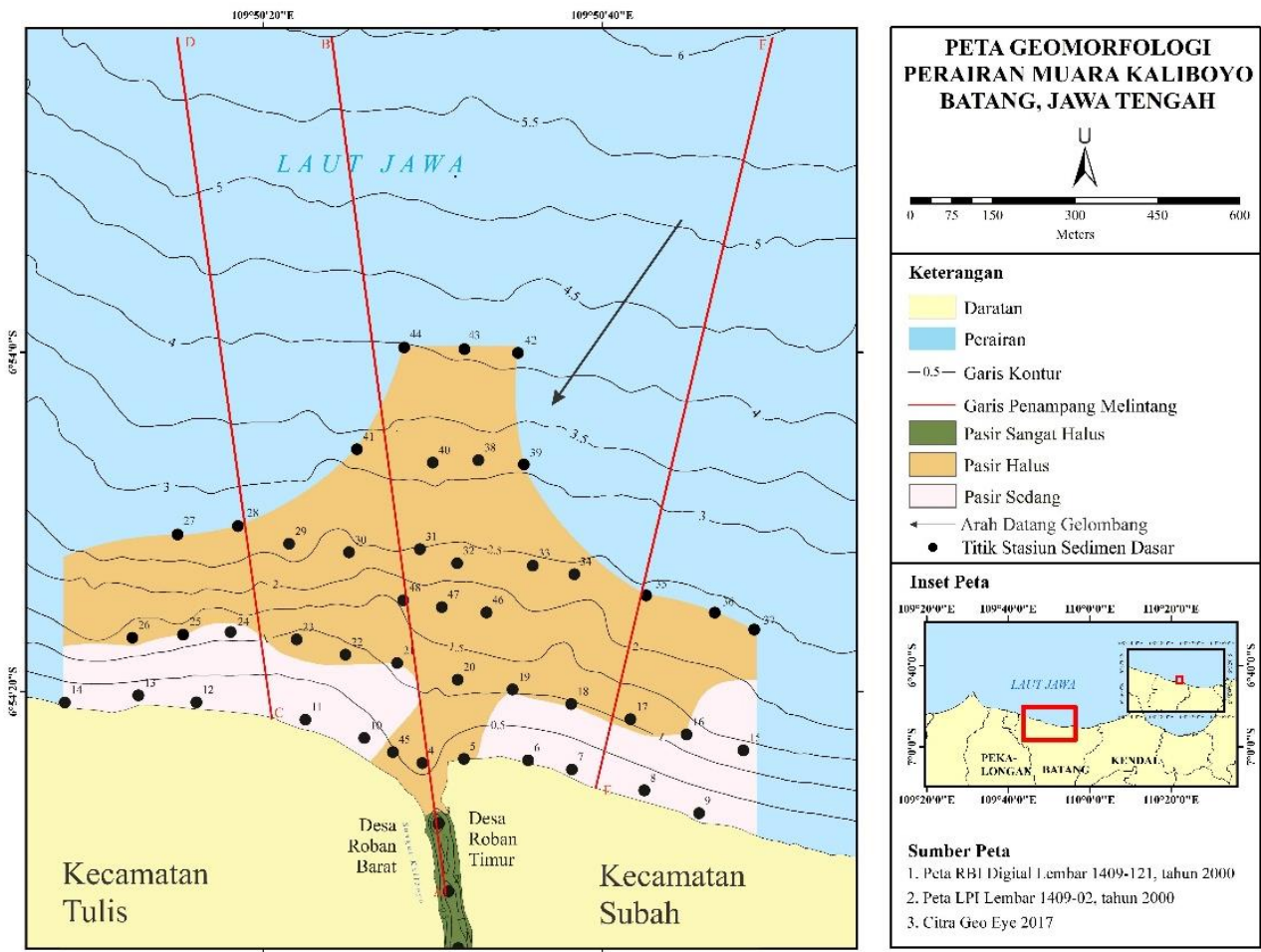

Gambar 4. Peta Geomorfologi Perairan Muara Sungai Kaliboyo


Skala Vertikal : Skala Horizontal $=1: 26,98$

Gambar 5. Peta Melintang Morfologi Perairan Muara Sungai Kaliboyo 


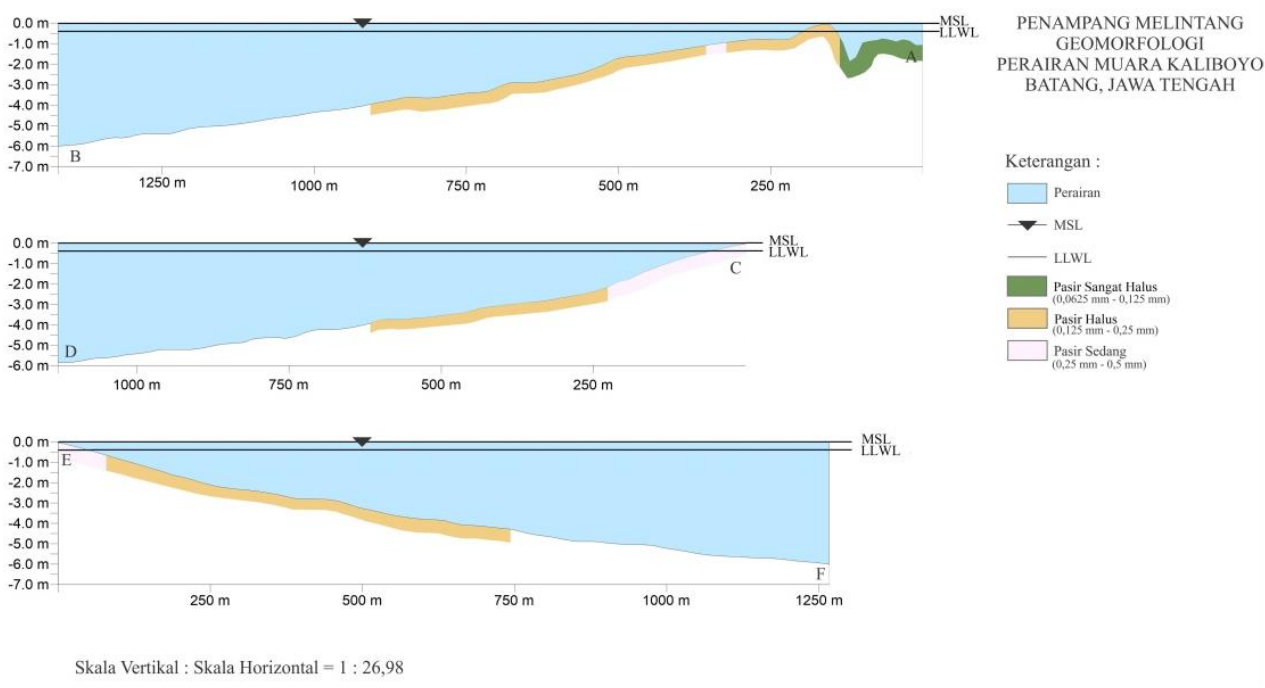

Gambar 6. Peta Melintang Geomorfologi Perairan Muara Sungai Kaliboyo

Tabel 1. Kemiringan Lereng Penampang Melintang

\begin{tabular}{|c|c|c|c|c|c|c|}
\hline Sayatan & Segmen & Ic $(\mathrm{m})$ & $\Delta h(m)$ & S (\%) & $\mathrm{S}_{\text {Rata rata }}(\%)$ & Klasifikasi \\
\hline \multirow{6}{*}{$A-B$} & $\alpha_{1}$ & 0.13 & 96.00 & 0.13541 & \multirow{6}{*}{1.96} & \multirow{6}{*}{ Datar } \\
\hline & $\alpha_{2}$ & 0.91 & 20.67 & 4.403006 & & \\
\hline & $\alpha_{3}$ & 1.76 & 33.34 & 5.279736 & & \\
\hline & $\alpha_{4}$ & 0.67 & 66.67 & 1.00495 & & \\
\hline & $\alpha_{5}$ & 1.95 & 387.35 & 0.503417 & & \\
\hline & $\alpha_{6}$ & 3.32 & 824.75 & 0.402546 & & \\
\hline \multirow{3}{*}{ C-D } & $\alpha_{1}$ & 2.09 & 283.35 & 0.73761 & \multirow{3}{*}{0.50} & \multirow{3}{*}{ Datar } \\
\hline & $\alpha_{2}$ & 1.6 & 379.35 & 0.421772 & & \\
\hline & $\alpha_{3}$ & 1.69 & 483.87 & 0.349267 & & \\
\hline \multirow{3}{*}{$E-F$} & $\alpha_{1}$ & 1.65 & 258.01 & 0.639503 & \multirow{3}{*}{0.47} & \multirow{3}{*}{ Datar } \\
\hline & $\alpha_{2}$ & 2.88 & 683.37 & 0.421442 & & \\
\hline & $\alpha_{3}$ & 1.16 & 342.35 & 0.338835 & & \\
\hline
\end{tabular}

Sisi kiri perairan memiliki kontur cenderung rapat. Pada bagian kanan perairan, terlihat kontur lebih renggang dan landai. Secara keseluruhan, nilai kemiringan yang didapatkan yaitu sayatan A-B dengan nilai 1,95\%, sayatan C-D dengan nilai $0,50 \%$, dan sayatan E-F dengan nilai $0,46 \%$. Berdasarkan nilai kemiringan, Perairan Muara Sungai Kaliboyo tergolong kelerengan kelas I berdasarkan klasifikasi Van Zuidam dengan rentang kemiringan $0-2 \%$ dan dikategorikan datar.

\section{KESIMPULAN}

Berdasarkan hasil penelitian dan analisis di perairan Muara Sungai Kaliboyo, Kabupaten Batang memiliki kondisi geomorfologi berupa pantai berpasir dengan didominasi gelombang dan debit sungai. Muara sungai terjadi pendangkalan hingga kedalaman 0,5 m. Kemiringan perairan berkisar $0,47 \%$ hingga $1,95 \%$ sehingga tergolong datar.

\section{DAFTAR PUSTAKA}

[BPS] Badan Pusat Statistik Kabupaten Batang. 2018. Kecamatan Subah Dalam Angka. Badan Pusat Statistik Kabupaten Batang, Batang

Colin, W. 2002. Coasts Form, Process and Evolution.New York.Cambridge University Press

Dinas Pustadaru, 2012. Daftar Daerah Aliran Sungai (DAS) per Wilayah Sungai (WS) di Jawa Tengah. Dinas Pekerjaan Umum Sumber Daya Air dan Penataan Ruang, Jawa Tengah 
Febrianto, T., Hestirianoto, T. \& Agus, S.B. 2015. Pemetaan Batimetri di Perairan Dangkal Pulau Tunda, Serang, Banten Menggunakan Singlebeam Echosounder. Jurnal Teknologi Perikanan dan Kelautan, 6(2):139-147

Poerbandono \& Djunarsjah, E. 2005. Survei Hidrografi. Refika Aditama, Bandung, 166 hlm.

Priyono, P. 2016. Metode Penelitian Kuantitatif. Sidoarjo: Zipatama Publishing

Soeprapto. 2001. Survei Hidrografi. Jurusan Teknik Geodesi Fakultas Teknik Universitas Gadjah Mada, Yogyakarta

Triatmodjo, B. 1999. Teknik Pantai. Beta Offset. Yogyakarta.

Van Zuidam, R.A., 1982. Considerations on systematic medium scale geomorphological mapping. Zeitschrift fur Geomorphologie, 26(4):473-480. 